\title{
Correction: Baseline Omega-3 Index Correlates with Aggressive and Attention Deficit Disorder Behaviours in Adult Prisoners
}

Barbara J. Meyer, Mitchell K. Byrne, Carole Collier, Natalie Parletta, Donna Crawford, Pia C. Winberg, David Webster, Karen Chapman, Gayle Thomas, Jean Dally, Marijka Batterham, Ian Farquhar, Anne-Marie Martin, Luke Grant

Information is missing from the first sentence of the "Ethics approval and recruitment of study participants" heading of the Methods section. The correct sentence is: This study was approved by the Department of Corrective Services NSW, Australia Ethics committee (11/ 93185) and the University of Wollongong Human Research Ethics Committee (NSA13/004).

\section{Reference}

1. Meyer BJ, Byrne MK, Collier C, Parletta N, Crawford D, Winberg PC, et al. (2015) Baseline Omega-3 Index Correlates with Aggressive and Attention Deficit Disorder Behaviours in Adult Prisoners. PLoS ONE 10(3): e0120220. https://doi.org/10.1371/journal.pone.0120220 PMID: 25793501

\section{f OPEn ACCESS}

Citation: Meyer BJ, Byrne MK, Collier C, Parletta N, Crawford D, Winberg PC, et al. (2018) Correction: Baseline Omega-3 Index Correlates with Aggressive and Attention Deficit Disorder Behaviours in Adult Prisoners. PLOS ONE 13(5): e0197231. https://doi.org/10.1371/journal. pone. 0197231

Published: May 7, 2018

Copyright: ๑ 2018 Meyer et al. This is an open access article distributed under the terms of the Creative Commons Attribution License, which permits unrestricted use, distribution, and reproduction in any medium, provided the original author and source are credited. 